DOI https://doi.org/10.18551/rjoas.2017-07.19

\title{
THE CONCEPT OF ETHICAL BEHAVIOR OF PUBLIC ACCOUNTANT BASED ON ISLAMIC SPIRITUALITY
}

\author{
Nursanty Ida Ayu* \\ STIE AMM Mataram \& Doctoral Degree Program in Accounting, \\ Faculty of Economics and Business, University of Brawijaya, Indonesia
}

\author{
Triyuwono Iwan, Mulawarman Aji D., Rosidi \\ University of Brawijaya, Indonesia \\ *E-mail: idaayunursanty29@yahoo.co.id
}

\begin{abstract}
The study aims at constructing the concept of ethical behavior of public accountant based on Islamic spirituality. This research adapts spiritualist paradigm and spiritualist research design to create behavioral concept based on Islamic spirituality. Through zikr (Islam: repeated confession of faith), prayer, and contemplation method, researchers obtained balance in terms of mind, justice, honesty, and love as the instruments to analyze data. This research shows that the balance of mind, justice, honesty, and love reflected in public accountant personality will lead the accountants to personality with humanist values, as the leader on Earth with trustworthy, spreading love to others, beyond the consciousness to be devoted and faithful to Allah God Almighty.
\end{abstract}

\section{KEY WORDS}

Public accountant, spirituality, Islam, good deeds, mind balance, justice balance, honesty balance.

In history, there have been some cases of the dark sides of accounting practices. Jones (2011: 15) has made an overview of the various cases of accounting scandals in various countries, including HIH Insurance (Australia), Zhenzhou Baiwen (China), ComRoad and Flowetex (Germany), Bank of Crete (Greece), Satyam (India), Parmalat (Italy), Kanebo, Livedoor, and Nikko Cordial (Japan), Royal Ahold (Netherlands), Afinsa and Forum, and Filatellico (Spain), ABB and Skandia (Sweden), and Polly Peck (England). The United States is also one country which is characterized by similar cases, namely Enron, Worldcom, Global Crossing, and Adelphia in which similar scandals occur (Albrecth et al., 2004: 110). Similar cases are also found in Indonesia for example in the case of Bank Bali, Bank Syariah Mandiri Bogor Branch, BN Bank, Bank Mandiri, PT Kimia Farma, and others.

There was an interesting case when we look to the past in relation with the statement of fraudulent cases related to the bankruptcy of the companies that were orchestrated by public accountants. According to the English bankruptcy law in 1831, the accountant should be appointed as the official assignees in bankruptcy cases. One who was appointed official assignees by Chancellor is Peter Abbot. Not in a glorious record, Peter Abbot became criminal and made note of fraud. Ten years after his appointment, Abbot instead fled to Brussels to take away money from the fraudulent cases amounted to more than 80,000 pounds (McPhaill, Walters: 2009).

The story underlines that the accounting profession has long been identical to the ethical issues; ethical violations could be as old as the accounting profession itself. Standards exist, however, that does not mean strong enough to withstand variety of fraud and creative criminals. How are ethics truly owned by a public accountant? This question is main part of this study.

The fraudulent cases provide crucial concern for the public accounting profession. According to Agoes (2014: 56) stated the theory of ethical egoism and utilitarianism (the two are often called teleological, consequences, or destination theories), the theory of liability 
(deontology), the theory of rights, as well as the theory of priority (virtue theory) or also known as the theory of character. Although these theories seem likely to be different, studies related to morality focus the same process that is based on the reasonable sense of humanity. These theories are the bases for the development of ethical principles of public accountants who then gain the many highlights of the researchers, criticizing the areas of the economy and business. That means, this is imminent to provide alternative ideas on the development of ethical-based spirituality. It is essential spirituality is working on the public accountants' minds rights, guided by revelation to God, leading to the construction of the new ethic of good public accountants.

\section{METHODS OF RESEARCH}

To determine the appropriate research method, the researchers needed to understand the current problems in the area of public accountant. As a way to investigate the facts and concepts (Usman, 1984: 385-36) and with regard to the explanation of the ethical behavior (Islam: akhlakul karimah) of public accountants, the method employed in this study was researchers' intuition through zikr (Islam: repeated confession and remembrance of faith), prayer, and contemplation (Islam: tafakkur) (Triyuwono, 2015).

According to Triyuwono (2006), the intuition will enable the spiritual energy which can be used to obtain information directly from the God, for spiritual energy to connect with the Creator. In addition, Triyuwono (2015) stated that the way to gain knowledge through intuition by doing zikr, prayer, and tafakkur is through the following procedures: first to access the energy of Allah (through remembrance of faith or zikr); a person may interact in such way with deep devotion and awareness to ultimately gain inspiration (Aman 2014; 2013; Newberg and Waldman, 2009).

The procedure for prayer applied to God in order to be granted with wisdom in the form of capacities to obtain idea of what the best and suitable ways in analyzing the available data. Prayer really complements the awareness and presence of heart (Frager, 2013: 361). Praying by considering the presence of God is significant goodwill, which we believe firmly that God is fully present even though we do not experience His presence in physical sensory. We also believe that He watches and listens to our prayers. Despite we may think of being away from Him, we have to believe that there is no dividing curtain between us as humans and God (Frager, 2013: 366). And the third is always thinking and contemplating (tafakkur) will be analyzed, discussed and argued.

Data Collection Technique. This study focused on a specific site in data collection and determined some informants whom will be interviewed in to gain in-depth data. The data obtained from the informants will be utilized to develop the concept of ethical behavior of the public accountants based Islamic spirituality, through interpretation and reflection of the researchers. Through the interview, the researchers tried to minimize their influence with neutral but critical stance and focused on the structured questions. All forms of expression were noted and reported to be pursued in order to avoid a single and biased interpretation (Denzin \& Lincoln, 2009: 511-512).

Literature Review. Some of the books used by the researcher are associated with Islamic spirituality, good behaviors and moral psychology, written by Imam Ja'far al-Sadiq, Haidar Bagir, Motahhari, and Imam Jamal Rahman. The literature review is intended to obtain a broad horizon in developing the concept of ethical conduct good public accountant based on Islamic values.

\section{RESULTS AND DISCUSSION}

The Characteristics of Good Behaviors (Akhlakul Karimah) as Tool of Analysis. According to the views by Imam Ja'far Shadiq as described by Muhammad and Zainuddin (2014) that psychologically, the concept of akhlakul karimah in Islam has four characteristics very. The four characteristic are namely the balance in terms of mind and thinking, justice, honesty, and love. The characteristic of akhlakul karimah firstly concerns with mind aspect, 
that the balance of mind is intended to lead into the righteous balance in the array of solid towards the glory of the people of the highest life.

The second character is justice. Justice is putting all power under the influence of rationality, in which each of these powers is given its full rights. The perfect provision of rights will create a just and social state so that the life order will be built in a solid manner to the highest prosperity of the people.

The third characteristic is honesty. Honesty is the behavior that occurs in the words consistent with the deeds; the fair is the compatibility between reality and belief. Imam Shadiq said, "Whoever speaks honestly, it works sacred". In fact, according to the tenets of the celestial, must be honest is the legal basis of the provisions of law: "God did not send a prophet except with sincerity in the talks and to fulfill the mandate of the good and the bad".

The fourth is love. There are different views about the meaning of love. A philosopher said that love is a natural tendency toward something you like, something compatible. As a wise saying, love is a hidden power that makes lovers as part of his lover. In fact, love can transform them into one and inseparable. And the poet says love is the spirit of the glitter in the spirit and heart to heart contact (Muhammand \& Zainuddin, 2014: 132).

Meanwhile, the imam named love as in faith, "Is there any faith other than love?" Love is the main connection between the slave and his Lord; it is a strong relationship between man and religion. Therefore, the relationship between Muslims should be built under the supports of love and a glimmer of light. Therefore, "the love of one's religion is the love of other people".

Drilling Characters of Certified Public Accountants in the Perspective of RationalMateriality. Starting from the self-experience of the researchers in the approach to the subject as the informant (within the public accountings) was something very interesting. Attractive in a sense, what the informant through his speech, his behavior represents public accountant itself. The viewpoint of the public accountant in understanding his work is strongly influenced by his religion, spiritual, experience, and also his cultural background. These factors affect how the public accountant utilizes his knowledge in carrying out his duties as a professional (accountant). The dimensions take the biggest part that will be influential in shaping the character of a public accountant. Thus, how big do the factors affect the selfpublic accountant who will become his personal characteristic? Would public accountant view the material-rational, or would it change the consciousness of the public accountants for the higher dimension of the public accountant spiritual?

According to Abduh in his book Science of Tawheed related to the concept of justice stated that:

"Human-looking materiality is human tendency to use the power of his mind as the main pillar for their mind is the path of truth, intellect above everything. They negated even in matters of supra-rational, even revelation. Their mind had settled on the culture of materialism."

Researchers asserted that people are actually both physical as well as spiritual beings. However, the existence of a core of a human being is his spirituality. If there is a human tendency and busy taking care of physical things (material) compared with the spiritual, it is more likely related to the importance of materiality. In the field of public accountants, we may see how the image of the behaviors of the public accountants in performing their professional duties that the behavior is likely to materiality or spiritual.

Public Accountant Materialistic-Rational Triggers Ethics Violations. Many factors may influence a public accountant to either comply with or violate ethics. Some of these factors are as follows:

Mental Greediness (Greedy). If the individual concern has been already mentally "greedy", then he will act greedily at any opportunities he has, without concerning with the rules that set it up. Citing a statement from Mr. Nur Mokhlas Aryo Sukaimi as follows:

"(in relation with) the accounting scandals that occurred involving public accountant, if we learn of the case, I read this is due to greed factor (greediness) and also weak law enforcement. So if the mental is greedy, it is always greedy for any property and power to 
achieve the goal by all means, measuring everything from the material and the glory is measured by the material"

There are efforts should be taken to overcome this problem, by not giving any opportunity for the mental greediness to escape from the disruption. The solution is by setting a strict law for the (problematic) public accountants. Mr. Nur Mokhlas Iryo Sukaimi said that:

"If the law is applied and enforced fairly and firmly, then people will think the twice upon greedy mentality upon their daily acts. Through law enforcement, the acts of mental greediness could be stopped."

In addition to law enforcement and the application of strict and firm law, other effort that should be done is to provide training related to the development of spirituality within the public accountants aside from the professional efforts conducted by the majority of companies during the selection; that is to look for the candidates with good ethics. In addition the company also should back up the accountants with the code of conduct. Mr. Nur Mokhlas Iryo Sukaimi as a public accountant has to do with the selection of states that:

"The problem in the world of business professionals is recruiting the best talent. My position allows it; as a teacher in the field of auditing, I started to recruit students who are best academically and their attitude to work in my office. I should also act as a role model and mentor for their work with their expectations with a perfect career path, and also the way to achieve the career path well."

This is how public accounting function in the balance of their mind to curb the rapid growth of accounting scandals that occurred amidst business competition today.

"Traverse" Mentality: What Public Accountants Do Not Care. The cases of the accounting scandals that occurred today have also been caused by the unethical behavior of the public accountants called "traverse" mentality, which is the mentality surpassing the identical way to take a shortcut done by a particular public accountant in order to achieve goals easily (Faisal, 2016: 195).

Through the interview with Mr. Joko Priyono in relation with the mental traverse performed by the public accountants, he argued that:

"Through my experience, I've seen how some fancy colleagues, and I think reasonable when they with their knowledge, competencies, and skills possessed could provide a way out of their clients' cases and succeed. The solution was legal. It has been still on the right track, and they did not violate the law. They clients are satisfied with the services. The problem, this is pretty much the amount, CPAs provide a solution to the clients who have done their business illegally; even in violation of the law and not based on knowledge, competencies, and skills are adequate. Their original knowledge to the evidence is the knowledge of "negotiable". Then they could enrich themselves from the results of such services. No professional responsibility at all, by any means."

Mental traverse performed by the public accountants who did not take their life at stake to do things that may violate the rules of professional. Perhaps this is good for the accountants and also for their clients equally; no party is abused, but both are very lucky for the practices; public accountants are lucky for doing their job and hope to achieve the agreed fee services, and the client is also lucky because his intentions may be accomplished in accordance expectations through the services. Behind the practices, there are victimized, for example the government, shareholders, investors, or other stakeholders. In time, it will destroy the business itself and all the elements involved due to the idea of a public accountant who worship material.

Mentality surpass is closely associated with behavior "not appreciate the quality of performance". Importantly, the perpetrator may achieve its goals and objectives by taking shortcuts, not procedural. Traversing mentality seems undiminished; even in increasingly conduct by the public accountants in performing their professional duties. This phenomenon can be seen in the real scandals of financial accounting that have occurred in this country. Baidlowi (2016: 269) said "This was said in the Sheikh Abdul Qadir Jilani's sage as people who do not have a heart are who do not care about truth and virtue, subject only to the physical senses alone. They are stupid people and despised, there is no good in them." 
Epistemic Inequality: Triggering Conflict of Interest among Public Accountants. Noteworthy also is that in the middle of a conflict of interests, in particular personal interests and the interests of the institution where the professional work, there is a danger demands of professionalism compromised. In the pressure demands of interests, whether personal or institutional, the professional is no longer sufficient independent and autonomous to implement judgments and take decisions according to the demands of professionalism (May, 1994: 67-81).

The temptation to deviate from the demands of professionalism has made easier by the fact there is an imbalance between the epistemic professional and his client; confidence will lead to self-knowledge professionals on the one hand and less or even no knowledge of the client's adequacy. On the other hand, the activities that are being faced with the professional may push for abusing his position for his own benefit or the institution in which he works.

"Loser" Mentality of Public Accountant. According to Mustafa (2014: 226) that it cannot be called as public accountants those choose a bad way or being "losers". They did not reveal the heroic story, but it appears to be a loser because of their behavior. They are cheating accountants, breaching the ethics; the way is very diverse and clever, from polishing, enhancing, to manipulating the financial statements that are managed and intended to fool the government, investors, or other stakeholders. They support the crime to the detriment several parties. There are many public accountants, but not a few public accountants who behave badly. They are the "bad apples" in a basket, infecting other ripen apples. Why do "bad apples" occur? The answer lies on the ethical problem.

In an interview with investigators Mr. Hariadi, he expressed his views that:

"On the other hand, public accountants with good spiritual qualities, while doing professional duties they (CPA) will carry out their duties without being affected by materialistic and quantitative matter, but hunting the quality of values in life. A public accountant who has good spiritual, he will always train himself with good behavior and manners. He will work with the wisdom of his mind, honestly, fairly, and with full of love."

The above statement is the accusation of the characteristics of a good public accountant. It (CPA) will always point to the whole spiritual behavior qualities, not budging on material affairs (corporate); they will conduct accounting with high spirituality and will be a "hero" and help saving the economy in a sustainable manner. Because he (CPAs) is well aware that almost all sectors need hand touch-deft hand.

\section{CONCLUSION}

The conclusion of this study is to reveal the public accountant him/herself, an extreme conclusion that is not just static confining them in one rule. The personality of public accountant is stated that the researchers said that their perspective is beyond themselves, whether individual can or cannot do an act. Good and holy behavior is reaping the rewards, discipline, law-abiding in the region should be conducted; conversely, a bad behavior in the region cannot and should not be done.

Researchers realized that ethical principles have a duty not only to create rules for public accountants unless the problems are overcome by the good public accountant. Public accountants who have good foundation and intention means they have the sense of balance in terms of mind, justice, honesty, and love that overcomes these assessments can or cannot conduct public accountant.

The methodology through akhlakul karimah is morally judgmental, as we understand the ethical principles of public accounting; it also does not contain normative characteristic, but would like to present an effective enlightenment on values that must exist within a public accountant. Akhlakul karimah characteristics brushed perspective the life of a public accountant who prioritizes the view of life. The idea of akhlakul karimah characteristic features the creation of depth-reflection that may enrich humanist values into the consciousness of the public accountant (beyond consciousness). 


\section{REFERENCES}

1. Albrecht, W.S., Albrecht. C.C., \& Albrecht, C.O. (2004). Fraud and Corporate Executives: Agency, Stewardship and Broken Trust. Journal of Forensic Accounting, 5, 109-130.

2. Aman, S. 2013. Bashirah Teknologi Pemberdayaan Diri. Tangerang: Ruhana.

3. Bakar, O. 2008. Tauhid dan Sains: Perspektif Islam Tentang Agama dan Sains. Revisi. Bandung: Pustaka Hidayah.

4. Bladon, L. 2007. The Science of Spirituality: Itegrating Science. Psychology, Spirituality, and Religion. NP: EsotericScience.

5. Cresswell, J.W. 2005. Educational Research: Planning, Conducting, and Evaluating Quantitative and Qualitative Research. New Jersey: Pearson Education.

6. Denzin, N.K \& Lincoln, Y.S. 2009. Handbook of Qualitative Research. Yogyakarta: Pustaka Pelajar.

7. Erikson, P. \& Kovalainen, A. 2008. Qualitative Methods in Business Research. London: Sage

8. Frager, R. 2014. Obrolan Sufi: Untuk Transformasi Hati, Jiwa, dan Ruh. Jakarta: Zaman.

9. Gee, J. 1999. Intuition: Awakening Your Inner Guide. Boston: Weiser Book.

10. Jones, M. (Ed.). 2011. Creative Accounting, Fraud and International Accounting Scandals. Chichester, West Sussex: John Wiley and Sons, Ltd.

11. May, L. 1994. Conflict of Interest, dalam Professional Ethics and Social Responsibility. Maryland \& Littlefield Publisher, Inc.

12. McPhail, K. Walter, D. 2009. Accounting and Business Ethics. Routledge.

13. Muhammad, A \& Zainuddin, A. Psikologi Akhlak: Risalah Akhlak Imam Ja'far Shadiq dari Kebaikan, Kebahagiaan Menuju Kesempurnaan. Yogyakarta: Rausyan Fikr Institute.

14. Mustofa, A. 2005. Bersatu dengan Allah. Surabaya: Padma Press.

15. Mustofa. 2014. Manajemen Modern Bisnis Kantor Akuntan. Jakarta: Kompas.

16. Newberg, A. \& Waldman, M.R. 2009. How God changes your brain. New York: Ballantine Books.

17. Syamhudi, M.H. 2015. Akhlak Tasawuf: Dalam Konstruksi Piramida IImu Islam. Malang: Madani Media.

18. Triyuwono, I. 2015. Akuntansi Malangan: Salam satu jiwa dan konsep kinerja klub Sepak Bola. Jurnal Akuntansi Multiparadigma, 6 (2), 1175-340.

19. Triyuwono, I. 2006. Perspektif, Metodologi dan Teori Akuntansi Syariah. Jakarta: Radja Grafindo Persada.

20. Triyuwono, I. 2015. Awakening the conscience inside : the spirituality of code of ethics for professional accountants. Procedia - Social and Behavioral Sciences, 172, 254-261. 